\title{
Association of Tumor Necrosis Factor-Alpha -308 G>A Polymorphism With Rheumatoid Arthritis in Two North Indian Cohorts
}

\author{
Priyanka RAINA, ${ }^{1}$ Kawaljit MATHAROO,${ }^{1}$ Ajay KUMAR, ${ }^{2}$ Priyanka SARANGAL, ${ }^{1}$ \\ Rubina SHARMA, ${ }^{1}$ AJS BHANWER ${ }^{1}$ \\ ${ }^{1}$ Department of Human Genetics, Guru Nanak Dev University, Amritsar, Punjab, India \\ ${ }^{2}$ Immunology Group, International Centre for Genetic Engineering and Biotechnology, New Delhi, India
}

\begin{abstract}
Objectives: This study aims to analyze the role of tumor necrosis factor-alpha -308 G>A polymorphism with susceptibility to rheumatoid arthritis (RA) in population of Punjab, Jammu and Kashmir.

Patients and methods: A total of 251 blood samples were collected comprising 131 samples from Punjab (cohort 1) (40 RA positive and 43 RA negative and 48 healthy controls) and 120 samples from Jammu and Kashmir (cohort 2) (44 RA positive, 36 RA negative and 40 controls). Genotyping was based on amplification refractory mutation system-polymerase chain reaction, followed by agarose gel electrophoresis.

Results: In both the cohorts, higher percentages of females were observed to be affected than males (67.8\% in cohort 1 and $65 \%$ in cohort 2 ). The frequency of A-allele in cohort 1 and cohort 2 was $10.2 \%$ and $18.8 \%$ in cases, respectively, while it was $7.9 \%$ and $23.2 \%$ in controls, respectively. In cohort 2, sex-specific association in males with RA was observed, whereas no similar association was observed in cohort 1. RA patients presented with lower values for profiles of adiposity, suggesting association of weight loss with progression of RA.

Conclusion: Tumor necrosis factor-alpha -308 G>A polymorphism does not seem to play a significant role in predisposition to RA in North Indian population of Punjab, Jammu, and Kashmir.

Keywords: Rheumatoid arthritis; tumor necrosis factor-alpha.
\end{abstract}

Rheumatoid arthritis (RA) is a chronic autoimmune disease that affects $1 \%$ of the population worldwide. ${ }^{1}$ It is a systemic disease which involves the organs, joints, and other areas of body such as the eyes, lungs, heart, kidney, spleen, and skin. ${ }^{2}$ RA exhibits multifactorial inheritance resulting from a complex interplay between an individual's genetic background and environment. ${ }^{3}$ It has a complex etiology, including a wide spectrum of clinical manifestations, variability in disease severity, progression, and response to therapies. ${ }^{4}$ The genetic clues indicating RA were demonstrated in twin studies which show higher concordance rate for monozygotic twins (15\%) than dizygotic twins (4\%) with higher prevalence in first degree relatives $(4.38 \%)$ than second degree relatives $(1.95 \%){ }^{5}$
Extensive pathogenetic studies have shown that insults in both innate and adaptive immune response are involved in the pathogenesis of RA. ${ }^{6}$ Immune response mediated in RA patients shows both type III (immune complex mediated) and type IV (T cell-mediated) hypersensitivity. ${ }^{2,7}$ Over expression of proinflammatory and antiinflammatory cytokines such as tumor necrosis factor-alpha (TNF- $\alpha$ ), interleukins and interferons have been observed in serum of RA patients. It has been suggested that the altered expression of these cytokines leads to complex immune cascade causing tissue injury and inflammation. ${ }^{8,9}$

Tumor necrosis factor-alpha is a potent proinflammatory and immunoregulatory cytokine. TNF- $\alpha$ has a broad spectrum of biological activities with diverse functions in humans including

Received: January 03, 2014 Accepted: June 25, 2014 Published online: October 12, 2014

Correspondence: Kawaljit Matharoo, Ph.D. Department of Human Genetics, Guru Nanak Dev University, Amritsar 143005, Punjab, India.

Tel: 9501114487 e-mail: matharookawal@gmail.com

O2014 Turkish League Against Rheumatism. All rights reserved. 
induction of apoptosis, regulation of lymphocyte proliferation, upregulation of proteolytic enzymes, chemokines, and pathogenesis of wide range of complex diseases including RA. ${ }^{10}$ The gene encoding TNF- $\alpha$ is located within the highly polymorphic major histocompatibility complex region on chromosome 6p21.3. ${ }^{11}$ Elevated protein levels of TNF- $\alpha$ have been reported in synovial fluid and synovial tissue of RA patients. ${ }^{12}$ Expression analysis in a transgenic mouse model revealed that over expression of TNF- $\alpha$ leads to development of chronic arthritis resembling RA. ${ }^{13}$ Genetic variations like microsatellites and single nucleotide polymorphisms (SNPs) in the regulatory and functional regions of TNF- $\alpha$ gene are known to dictate the levels of the protein. Genetic polymorphism at -308 guanine>adenine $(G>A)$ in the promoter region has also been reported to influence TNF- $\alpha$ protein levels. ${ }^{14,15}$ Several studies have shown the association of $-308 \mathrm{G}>\mathrm{A}$ transition with RA. ${ }^{14-21}$ Keeping in view the role of inflammatory pathway in pathogenesis of RA and the influence of promoter polymorphisms in defining the protein levels and hence the disease susceptibility, the present study aims to analyze the association of TNF- $\alpha-308$ promoter polymorphism in RA patients from Punjab, Jammu, and Kashmir.

\section{PATIENTS AND METHODS}

This is a case-control association study of which its design has been approved by the ethics committee of Guru Nanak Dev University. A total of 251 blood samples were collected from two North Indian states, comprising 131 samples $(95$ females; mean age $46.85 \pm 12.52$; range 25 to 74 years and 36 males; mean age $42.05 \pm 12.64$; range 25 to 65 years) from Punjab (cohort 1 ), and 120 samples ( 80 females; mean age $44.43 \pm 13.58$; range 30 to 75 and 40 males; mean age $47.75 \pm 12.27$; range 28 to 76 years) from Jammu and Kashmir (cohort 2). Samples from Punjab were collected from government and private hospitals including individuals from Amritsar, Gurdaspur, Jallandhar, and Ludhiana regions. Samples collected from hospitals of Jammu had individuals from Jammu as well as Kashmir. Samples from Punjab included 83 patients with RA (40 RA positive and $43 \mathrm{RA}$ negative) and 48 healthy controls. Samples from Jammu and Kashmir constituted 80 patients with RA (44 RA positive and 36 RA negative), and 40 controls without RA. Patients with RA were divided into RA positive and RA negative according to the presence of rheumatoid factor (RF). Inclusion criteria included individuals clinically diagnosed as having RA by expert physicians according to the revised criteria of American College of Rheumatology. ${ }^{22}$ Individuals with no history of joint pains were enrolled as healthy controls, and matched for age and ethnicity with patients of RA. After obtaining their informed consent in writing, 3-5 ml venous blood was drawn with sterile syringe, and immediately transferred into a pre-labelled blood collection vial containing anticoagulant $(0.5 \mathrm{M}$ EDTA). Other information about each donor such as age, sex and anthropometric measurements comprising of height, weight, waist circumference (WC) and hip circumference (HC) were recorded on donor documentation form for further analysis viz calculating the body mass index and waist hip ratio (WHR).

Genomic DNA was isolated from the venous blood using an inorganic method with slight modification according to laboratory conditions. ${ }^{23}$ Red blood cell lysis buffer composition 0.001 M EDTA, 0.01 M TRIS, $0.125 \mathrm{M} \mathrm{NH}_{4} \mathrm{Cl}$, and $7.5 \mathrm{M}$ ammonium acetate was used for red blood cell lysis and precipitation of proteins, respectively. The quality of DNA samples was detected on $0.8 \%$ agarose gel with ethidium bromide staining. ${ }^{24}$ The DNA samples were quantified using ultraviolet spectrophotometer. The DNA samples were diluted to a working concentration of $20 \mathrm{ng} / \mu \mathrm{l}$. TNF- $\alpha-308 \mathrm{G}>\mathrm{A}$ polymorphism was analyzed by the amplification refractory mutation systempolymerase chain reaction. Primers specific for $A$ and $G$ allele amplified the respective allele fragments yielding $273 \mathrm{bp}$ product. The primer pair used to amplify the target region for $-308 \mathrm{G} / \mathrm{A}$ polymorphism in TNF- $\alpha$ gene was as described by Gupta and Sehejpal. ${ }^{25}$ Amplification was carried out in $15 \mu \mathrm{l}$ reaction with $40 \mathrm{ng}$ of DNA, $200 \mu \mathrm{M}$ of dNTPs, $0.17 \mu \mathrm{M}$ of each primer, $1 \mathrm{X}$ Taq polymerase buffer $(1.5 \mathrm{mM} \mathrm{MgCl}, 50 \mathrm{mmol} \mathrm{KCl}, 10 \mathrm{mmol}$ Tris- $\mathrm{HCl}$, and $0.01 \%$ gelatine], and $0.36 \mathrm{U}$ of Taq DNA polymerase (Bangalore Genei). Genotyping was done on ethidium bromide stained 1.5\% agarose gel using 100 bp ladder as molecular weight marker. 


\section{Statistical analysis}

The continuous variables are represented as mean value \pm standard deviation (SD). Body mass index is given as $\mathrm{kg} / \mathrm{m}^{2}$, and $\mathrm{WC}$ and $\mathrm{HC}$ in $\mathrm{cm}$. Body mass index cut off values used for overweight and obese were as recommended for the Asian Indians (body mass index $\geq 23$ ). ${ }^{26}$ Genotypes and allele frequencies are represented as percentages and the frequencies were calculated by gene counting method. The distribution of genotype [guanine-guanine (GG), guanine-adenine (GA), adenine-adenine (AA)] and allele ( $G$ and $A$ ) frequencies in patients with RA and control was compared by $3 \times 2$ and $2 \times 2$ Chi-square contingency tables, and extent of association was detected by odds ratio (OR) at 95\% confidence interval (CI). Significance was detected at $5 \%$ level $(p<0.05)$. The statistical analyses were performed using IBM SPSS Statistics for Windows, version 20.0 (IBM Corp., Armonk, New York, USA).

\section{RESULTS}

Various clinical characteristics of the patients and controls is shown in (Table 1). The results of the two populations are represented separately.
Cohort 1: Mean age was comparable in patients $(45.78 \pm 12.28)$ and controls $(45.10 \pm 13.04)$. The percentage of females affected from RA was higher (68.7\%) than males (31.3\%). In controls, the percentage of females was $79 \%$. The WC of patients was smaller than controls $(81.08 \pm 8.36$ vs. $84.94 \pm 11.30$, respectively), and the difference was statistically marginally significant $(p=0.043)$. Similarly, the $\mathrm{HC}$ of patients was smaller than controls (95.18 \pm 9.83 vs. $99.52 \pm 12.80$, respectively). Here again, the differences were only marginally significant $(p=0.046)$. Body mass index was lower in patients than controls $(24.43 \pm 3.81$ vs. $25.66 \pm 4.64$, respectively) with no statistically significant difference. Waist hip ratio was similar in patients and controls $(0.853 \pm 0.039$ and $0.854 \pm 0.048$, respectively) with no significant difference.

Cohort 2: Mean age was $44.09 \pm 13.60$ in patients of RA, and $46.90 \pm 12.66$ in controls with no statistically significant difference. Here again, the number of affected females from RA (65\%) was higher than males (35\%). The percentage of females in controls was $70 \%$. Body mass index was lower in patients with RA $(23.73 \pm 2.80)$ than controls $(24.78 \pm 3.13)$. WC was

Table 1. Comparison of clinical characteristics of rheumatoid arthritis patients and controls from the populations of Punjab; and Jammu and Kashmir

\begin{tabular}{|c|c|c|c|c|c|c|c|}
\hline \multirow[t]{2}{*}{$\begin{array}{l}\text { Punjab population } \\
\text { (cohort 1) }\end{array}$} & $\begin{array}{c}\text { Total RA } \\
\text { patients }(n=83)\end{array}$ & $\begin{array}{c}\text { RA positive } \\
\text { patients }(n=40)\end{array}$ & $\begin{array}{l}\text { RA negative } \\
\text { patients }(n=43)\end{array}$ & $\begin{array}{l}\text { Controls } \\
(n=48)\end{array}$ & $\begin{array}{c}\text { Total RA } \\
\text { patients vs. } \\
\text { controls }\end{array}$ & $\begin{array}{l}\text { RA positive } \\
\text { patients vs. } \\
\text { controls }\end{array}$ & $\begin{array}{l}\text { RA negative } \\
\text { patients vs. } \\
\text { controls }\end{array}$ \\
\hline & Mean \pm SD & Mean \pm SD & Mean \pm SD & Mean \pm SD & $p$ & $p$ & $p$ \\
\hline Age (years) & $45.78 \pm 12.28$ & $47.30 \pm 11.34$ & $44.37 \pm 13.08$ & $45.10 \pm 13.04$ & 0.770 & 0.401 & 0.790 \\
\hline BMI $\left(\mathrm{kg} / \mathrm{m}^{2}\right)$ & $24.43 \pm 3.81$ & $25.08 \pm 0.59$ & $23.83 \pm 3.96$ & $25.66 \pm 4.64$ & 0.123 & 0.506 & $0.045^{*}$ \\
\hline $\mathrm{WC}(\mathrm{cm})$ & $81.08 \pm 8.36$ & $82.30 \pm 8.58$ & $79.95 \pm 8.08$ & $84.94 \pm 11.30$ & $0.043^{*}$ & 0.217 & $0.017^{*}$ \\
\hline $\mathrm{HC}(\mathrm{cm})$ & $95.18 \pm 9.83$ & $96.75 \pm 9.39$ & $93.72 \pm 10.11$ & $99.52 \pm 12.80$ & $0.046^{*}$ & 0.246 & $0.018^{*}$ \\
\hline WHR & $0.853 \pm 0.039$ & $0.851 \pm 0.046$ & $0.854 \pm 0.036$ & $0.854 \pm 0.048$ & 0.859 & 0.742 & 0.985 \\
\hline \multirow[t]{2}{*}{$\begin{array}{l}\text { Jammu and Kashmir } \\
\text { population (cohort 2) }\end{array}$} & $\begin{array}{c}\text { Total RA } \\
\text { patients }(n=80)\end{array}$ & $\begin{array}{c}\text { RA positive } \\
\text { patients }(n=44)\end{array}$ & $\begin{array}{c}\text { RA negative } \\
\text { patients }(n=36)\end{array}$ & $\begin{array}{l}\text { Controls } \\
(n=40)\end{array}$ & $\begin{array}{c}\text { Total RA } \\
\text { patients vs. } \\
\text { controls }\end{array}$ & $\begin{array}{l}\text { RA positive } \\
\text { patients vs. } \\
\text { controls }\end{array}$ & $\begin{array}{l}\text { RA negative } \\
\text { patients vs. } \\
\text { controls }\end{array}$ \\
\hline & Mean \pm SD & Mean \pm SD & Mean \pm SD & Mean \pm SD & $p$ & $p$ & $p$ \\
\hline Age (years) & $44.09 \pm 13.60$ & $43.23 \pm 13.63$ & $45.14 \pm 13.68$ & $46.90 \pm 12.66$ & 0.267 & 0.204 & 0.563 \\
\hline BMI $\left(\mathrm{kg} / \mathrm{m}^{2}\right)$ & $23.73 \pm 2.80$ & $23.69 \pm 2.99$ & $23.78 \pm 2.59$ & $24.78 \pm 3.13$ & 0.077 & 0.106 & 0.132 \\
\hline WC $(\mathrm{cm})$ & $86.20 \pm 4.61$ & $86.20 \pm 4.77$ & $86.19 \pm 4.48$ & $88.58 \pm 4.77$ & $0.011^{*}$ & $0.025^{*}$ & $0.028^{*}$ \\
\hline $\mathrm{HC}(\mathrm{cm})$ & $99.31 \pm 7.89$ & $99.11 \pm 7.80$ & $99.56 \pm 8.11$ & $102.25 \pm 7.85$ & 0.057 & 0.070 & 0.146 \\
\hline WHR & $0.871 \pm 0.06$ & $0.871 \pm 0.03$ & $0.870 \pm 0.08$ & $0.868 \pm 0.03$ & 0.069 & 0.590 & 0.860 \\
\hline
\end{tabular}

RA: Rheumatoid arthritis; BMI: Body mass index; WC: Waist circumference; HC: Hip circumference; WHR: Waist hip ratio. "P<0.05 is considered statistically significant. 
also higher in controls $(88.58 \pm 4.77)$ than patients $(86.20 \pm 4.61)$, and the differences in WC were statistically significant $(p<0.05)$. Distribution of other parameters in patients and controls revealed no significant difference.

Body mass index was slightly higher in cohort 1 $(24.43 \pm 3.81)$ than cohort $2(23.73 \pm 2.80)$, but this difference was not statistically significant ( $p>0.05)$. A similar trend was detected in controls $(25.66 \pm 4.64$ vs. $24.78 \pm 3.13)$ as well. However, both cohorts showed statistically significant differences for WC, HC and WHR in patients, and for WC and HC in controls (supplementary data table S1).

The TNF- $\alpha-308 \mathrm{G}>\mathrm{A}$ polymorphism was analyzed in RA patients with amplification refractory mutation system-polymerase chain reaction technique. The distribution of genotype and allele frequencies in overall and sex-specific RA patients (RA positive and RA negative) and controls in cohort 1 and cohort 2 are represented in Table 2. The patients and controls in both cohorts were within HardyWeinberg equilibrium.

Cohort 1: In controls, the frequencies of GG, GA and AA genotypes were 83.3\%, 16.7\%, and $0 \%$, respectively, while the frequencies for $\mathrm{G}$ and $\mathrm{A}$ allele were $91.7 \%$ and $8.3 \%$, respectively. In total patients, frequencies for GG, GA and AA genotypes were 81.9\%, 15.7\% and $2.4 \%$, and frequencies for $\mathrm{G}$ and $\mathrm{A}$ allele were $89.8 \%$ and $10.2 \%$, respectively. The frequency of GG genotype (88.4\%) and G allele (94.2\%) was higher in RA patients negative for RF. AA genotype was observed only in females, and its frequency was higher in females who were RF positive (6.4\%). In all groups, none of the males had AA genotype. The frequency of A allele was higher in RA patients positive for RF (15.0\%).

The frequency distribution in total and sex-specific RA positive and RA negative patients and controls were compared between different groups, the results of which are

Table 2. Distribution of genotype and allele frequencies of TNF- $\alpha-308 \mathrm{G}>\mathrm{A}$ polymorphism in overall and sex-specific RA patients, RA positive patients, RA negative patients, and controls in Punjab, and Jammu and Kashmir populations

\begin{tabular}{|c|c|c|c|c|c|c|c|c|c|c|c|c|}
\hline \multirow{2}{*}{$\begin{array}{l}\text { Punjab } \\
\text { population } \\
\text { (TNF- } \alpha-308 \text { G>A) } \\
\text { (cohort 1) }\end{array}$} & \multicolumn{3}{|c|}{ Total RA patients } & \multicolumn{3}{|c|}{ RA positive } & \multicolumn{3}{|c|}{ RA negative } & \multicolumn{3}{|c|}{ Controls } \\
\hline & $\begin{array}{l}\text { Total } \\
(\mathrm{n}=83)\end{array}$ & $\begin{array}{c}\text { Males } \\
(n=26)\end{array}$ & $\begin{array}{c}\text { Females } \\
(n=57)\end{array}$ & $\begin{array}{c}\text { Total } \\
(\mathrm{n}=40)\end{array}$ & $\begin{array}{l}\text { Males } \\
(\mathrm{n}=31)\end{array}$ & $\begin{array}{c}\text { Females } \\
(n=9)\end{array}$ & $\begin{array}{l}\text { Total } \\
(n=43)\end{array}$ & $\begin{array}{l}\text { Males } \\
(\mathrm{n}=17)\end{array}$ & $\begin{array}{c}\text { Females } \\
(n=26)\end{array}$ & $\begin{array}{l}\text { Total } \\
(n=48)\end{array}$ & $\begin{array}{l}\text { Males } \\
(n=10)\end{array}$ & $\begin{array}{c}\text { Females } \\
(n=38)\end{array}$ \\
\hline \multicolumn{13}{|l|}{ Genotypes } \\
\hline GG & 81.9 & 88.5 & 78.9 & 75.0 & 77.8 & 74.2 & 88.4 & 94.1 & 84.6 & 83.3 & 80.0 & 84.2 \\
\hline GA & 15.7 & 11.5 & 17.5 & 20.0 & 22.2 & 19.4 & 11.6 & 5.9 & 15.4 & 16.7 & 20.0 & 15.8 \\
\hline AA & 2.4 & - & 3.6 & 5.0 & - & 6.4 & - & - & - & - & - & - \\
\hline \multicolumn{13}{|l|}{ Alleles } \\
\hline G & 89.8 & 94.2 & 87.7 & 85.0 & 88.9 & 83.9 & 94.2 & 97.1 & 92.3 & 91.7 & 90.0 & 92.1 \\
\hline A & 10.2 & 5.8 & 12.3 & 15.0 & 11.1 & 16.1 & 5.8 & 2.9 & 7.7 & 8.3 & 10.0 & 7.9 \\
\hline \multirow{2}{*}{$\begin{array}{l}\text { Jammu and Kashmir } \\
\text { population } \\
\text { (TNF- } \alpha-308 \text { G>A) } \\
\text { (cohort 2) }\end{array}$} & \multicolumn{3}{|c|}{ Total RA patients } & \multicolumn{3}{|c|}{ RA positive } & \multicolumn{3}{|c|}{ RA negative } & \multicolumn{3}{|c|}{ Controls } \\
\hline & $\begin{array}{c}\text { Total } \\
(\mathrm{n}=80)\end{array}$ & $\begin{array}{l}\text { Males } \\
(\mathrm{n}=28)\end{array}$ & $\begin{array}{c}\text { Females } \\
(\mathrm{n}=52)\end{array}$ & $\begin{array}{l}\text { Total } \\
(n=44)\end{array}$ & $\begin{array}{l}\text { Males } \\
(n=13)\end{array}$ & $\begin{array}{c}\text { Females } \\
(n=31)\end{array}$ & $\begin{array}{c}\text { Total } \\
(\mathrm{n}=36)\end{array}$ & $\begin{array}{l}\text { Males } \\
(\mathrm{n}=15)\end{array}$ & $\begin{array}{c}\text { Females } \\
(n=21)\end{array}$ & $\begin{array}{c}\text { Total } \\
(\mathrm{n}=40)\end{array}$ & $\begin{array}{l}\text { Males } \\
(\mathrm{n}=12)\end{array}$ & $\begin{array}{c}\text { Females } \\
(\mathrm{n}=28)\end{array}$ \\
\hline \multicolumn{13}{|l|}{ Genotypes } \\
\hline GG & 66.2 & 71.4 & 63.4 & 68.2 & 84.6 & 61.3 & 63.9 & 60.0 & 66.7 & 60.0 & 66.7 & 57.1 \\
\hline GA & 30.0 & 28.6 & 30.8 & 29.5 & 15.4 & 35.5 & 30.6 & 40.0 & 23.8 & 30.0 & 8.3 & 39.3 \\
\hline AA & 3.8 & - & 5.8 & 2.3 & - & 3.2 & 5.6 & - & 9.5 & 10.0 & 25.0 & 3.6 \\
\hline \multicolumn{13}{|l|}{ Alleles } \\
\hline G & 81.2 & 85.7 & 78.8 & 83.0 & 92.3 & 79.0 & 79.2 & 80.0 & 78.6 & 75.0 & 70.8 & 76.8 \\
\hline A & 18.8 & 14.3 & 21.2 & 17.0 & 7.7 & 21.0 & 20.8 & 20.0 & 21.4 & 25.0 & 29.2 & 23.2 \\
\hline
\end{tabular}




\begin{tabular}{|c|c|c|c|c|c|c|}
\hline \multirow[t]{3}{*}{ TNF- $\alpha-308 \mathrm{G}>\mathrm{A}$} & \multicolumn{3}{|c|}{ Punjab population (cohort 1) } & \multicolumn{3}{|c|}{ Jammu and Kashmir population (cohort 2) } \\
\hline & Genotype & Allele & OR $(95 \% \mathrm{CI})$ & Genotype & Allele & OR $(95 \% \mathrm{CI})$ \\
\hline & $p$ & $p$ & & $p$ & $p$ & \\
\hline \multicolumn{7}{|c|}{ Total patients vs. controls } \\
\hline Total & 0.553 & 0.613 & $1.25(0.52-3.03)$ & 0.378 & 0.261 & $0.69(0.36-1.32)$ \\
\hline Males & - & 0.527 & $0.55(0.09-3.37)$ & $0.013^{*}$ & 0.118 & $0.40(0.13-1.28)$ \\
\hline Females & 0.484 & 0.335 & $1.64(0.60-4.55)$ & 0.710 & 0.764 & $0.88(0.41-1.92)$ \\
\hline \multicolumn{7}{|c|}{ RA positive patients vs. controls } \\
\hline Total & 0.256 & 0.165 & $1.92(0.75-5.0)$ & 0.313 & 0.205 & $0.62(0.29-1.30)$ \\
\hline Males & - & 0.911 & $1.12(0.14-9.09)$ & 0.151 & $0.048^{*}$ & $0.20(0.04-1.10)$ \\
\hline Females & 0.247 & 0.133 & $2.22(0.77-6.67)$ & 0.949 & 0.769 & $0.88(0.37-2.08)$ \\
\hline \multicolumn{7}{|c|}{ RA negative patients vs. controls } \\
\hline Total & 0.178 & 0.074 & $2.27(0.91-5.56)$ & 0.770 & 0.542 & $0.79(0.37-1.69)$ \\
\hline Males & - & 0.274 & $0.27(0.02-3.23)$ & $0.041^{*}$ & 0.434 & $0.61(0.17-2.13)$ \\
\hline Females & - & 0.967 & $0.98(0.26-3.57)$ & 0.416 & 0.834 & $0.90(0.34-2.38)$ \\
\hline \multicolumn{7}{|c|}{ RA positive patients vs. RA negative patients } \\
\hline Total & 0.171 & 0.05 & $2.86(0.96-8.33)$ & 0.729 & 0.345 & $0.69(0.32-1.49)$ \\
\hline Males & - & 0.229 & $4.16(0.35-50.0)$ & - & 0.189 & $0.33(0.06-1.82)$ \\
\hline Females & 0.368 & 0.172 & $2.33(0.68-7.69)$ & 0.479 & 0.955 & $0.97(0.37-2.56)$ \\
\hline
\end{tabular}

shown in Table 3. The distribution of genotype and allele frequencies was not significantly different in most of the group comparisons, except for a marginally significant difference in the distribution of allele frequencies between RA positive and RA negative patients $(p=0.05)$. In this cohort, the frequency of $\mathrm{A}$ allele was lower in RA negative patients than RA positive patients $(5.8 \%$ vs. $15.0 \%)$. However, the OR was not suggestive of any association $(\mathrm{OR}=2.86$, 0.96-8.33 at 95\% CI) (Table 3).

Cohort 2: The frequencies for GG, GA and AA genotypes were $66.2 \%, 30.0 \%$, and $3.8 \%$ in patients while they were $66.0 \%, 30.0 \%$, and $10.0 \%$ in controls, respectively. The allelic frequencies for the $\mathrm{G}$ and $\mathrm{A}$ allele were $81.2 \%$ and $18.8 \%$ in patients, and $75 \%$ and $25 \%$ in controls, respectively (Table 2). Once again, the AA genotype was observed only in females with a higher frequency in RA patients with RF negative (9.5\%) followed by total RA patients (5.8\%) and RF positive patients (3.2\%). Guanine allele frequency was higher in RF positive RA patients (83\%) than RA negative patients (79.2\%) and controls (75\%).

Significant differences in genotype frequencies were observed in males between total RA patients and controls $(p=0.013)$, and also between RA negative patients and controls $(p=0.041)$ while allele frequencies were marginally significantly different in RA positive patients and controls $(p=0.048)$. The genotypes were also analyzed under different genetic models to further detect the association of respective genotypes with the disease. In total patient population, the frequency of AA genotype was $0.0 \%$ in male patients. Therefore, carriers of the minor allele were added $(\mathrm{GA}+\mathrm{AA})$ and analyzed against homozygotes for the wild-type allele (GG) (data not shown). However, no significant difference was observed under the dominant model when GG homozygotes were compared against individuals with $\mathrm{GA}+\mathrm{AA}$ genotype $(p=0.76)$. Similar trends were observed under dominant model in comparison of RA

Table 4. Comparison of minor allele frequency (-308 TNF- $\alpha$ A allele) in different world populations

\begin{tabular}{lc}
\hline Population & Frequency of A allele (\%) \\
\hline Jammu and Kashmir (North India) & 25.0 \\
Punjab (North India) & 8.3 \\
China $^{3}$ & 7.7 \\
Czech Republic $^{10}$ & 9.7 \\
North Sweden $^{19}$ & 24.0 \\
Saudi Arabia & \\
Japan $^{32}$ & 31.0 \\
Uttar Pradesh $^{33}$ (North India) $^{33}$ & 3.3 \\
Egypt $^{34}$ & 4.9 \\
Dutch & 3.1 \\
Netherlands $^{35}$ & 23.8 \\
Taiwan $^{38}$ & 19.0 \\
Iran $^{39}$ & 9.0 \\
\hline
\end{tabular}


positive patients with controls $(p=0.29)$, and RA negative patients with controls $(p=0.72)$.

The frequency of $\mathrm{A}$ allele and $\mathrm{AA}$ genotype was higher in RA patients of cohort 2 than patients of cohort 1 [(18.8 vs. 10.2) and (3.8 vs. 2.4), respectively]. The frequency of AA genotype was higher in cohort 1 than cohort 2 (5.0 vs. 2.3 , respectively) in RA positive patients.

\section{DISCUSSION}

Tumor necrosis factor-alpha plays a prominent role in inflammation, and has relevance to infectious and autoimmune diseases like RA. ${ }^{6}$ TNF- $\alpha$ production shows a wide variation with high and low producer phenotypes which led to great interest in both the regulation of the TNF- $\alpha$ gene, and the possible association of its variants with RA pathology..$^{13}$ Several polymorphisms have been studied in the promoter region of TNF- $\alpha$ gene of which $\mathrm{G}>\mathrm{A}$ substitution at -308 position was one of the most extensively investigated variant. 27,28 Many studies have suggested the functional implication of $-308 \mathrm{G}>\mathrm{A}$ polymorphism with higher levels of TNF- $\alpha$ transcription. ${ }^{29-31}$

To the best of our knowledge, this is the first study conducted in the population of Punjab, and Jammu and Kashmir for the association of TNF- $\alpha-308$ G>A polymorphism with RA. The frequency of TNF- $\alpha-308$ minor allele (A allele) observed in the control population of the present study was compared with other world populations, and the data is presented in Table 4. The frequency in the control population of Punjab (cohort 1) was 8.3\%, which was similar to Chinese $(7.7 \%)^{3}$ and Czech $(9.7 \%),{ }^{10}$ and higher than Japanese (3.3\%), Egyptian (3.1\%) populations, and the North Indian (4.9\%) population from Uttar Pradesh. ${ }^{32-34}$ The frequency in cohort 2 comprising the Jammu and Kashmir population (25\%) was nearly similar to that reported in European populations including North Swedish (24\%), ${ }^{19}$ Dutch (23.8\%), ${ }^{35}$ and Netherlands (19\%) ${ }^{36}$ but lower than Saudi Arabian $(31.0 \%)^{28}$ population. The frequency of $\mathrm{A}$ allele in Jammu and Kashmir was higher compared to the population of Punjab. When the frequency of A allele and AA genotype was compared in RA patients, the frequency was higher in Jammu and Kashmir population (18.8\% allele and 3.8\% genotype) than Punjab population (10.2\% allele, $2.4 \%$ genotype). The higher frequency of $\mathrm{A}$ allele and AA genotype in Jammu and Kashmir population probably reflects the effects of geographical and cultural constraints resulting in higher endogamy. Therefore, the effect of inbreeding in Jammu and Kashmir population could have lead to an increased minor allele frequency in the population. ${ }^{37}$

In both population groups, females were more affected than males $(65 \%$ in Jammu and Kashmir, and $68.7 \%$ in Punjab). This finding was in line with other studies from populations of France, America, Taiwan and Netherlands which have also reported higher percentage of female RA patients $(78 \%, 75.7 \%, 75.4 \%$, and $73.5 \%$, respectively). ${ }^{36,38-40}$ The results implied that sex may have a significant effect on susceptibility to RA, with the disease being three times more frequent in females than in males. Moreover, it has been reported that hypoandrogenicity is responsible for RA in younger women..$^{41}$ Estrogen produced in females may lead to enhanced antibody production, whereas antibody production is suppressed by androgen in males, causing the sex-specific differences in RA. ${ }^{42,43}$ In the population of Jammu and Kashmir, significant association of TNF- $\alpha-308$ genotypes was found in total RA males cases and RA negative cases while marginal association was observed in RA positive cases and -308 alleles, suggesting a sex specific association of TNF- $\alpha-308 \mathrm{G}>\mathrm{A}$ polymorphism in this population. (Table 3). However, further studies on a larger sample size are required to confirm these findings.

Body mass index was higher in the population of Punjab while the WC was higher in Jammu and Kashmir population suggesting higher prevalence of generalized obesity in Punjab region, and central adiposity in the population of Jammu and Kashmir. The differences are indicative of increasing prevalence of central obesity in population of Jammu and Kashmir; however, analysis on a larger sample size is required to confirm the findings. Results of the present study contradict other studies from Punjab and national family health survey-3 report, which suggest higher prevalence of generalized as well as central obesity in the population of Punjab. ${ }^{44,45}$ In both cohorts, the RA patients had lower values for obesity profile than the controls. The differences 
may be a result of the selection of patients, as the present study is based on RA patients. Furthermore, most RA patients are advised weight control by doctors as excess weight may worsen their condition. Normally, weight loss is associated with the progression of RA. Additionally, TNF- $\alpha$ has been associated with accelerated metabolism, muscle protein breakdown, and muscle atrophy. Therefore, increased levels of this cytokine may eventually lead to weight loss. ${ }^{46,47}$

The role of TNF- $\alpha-308 \mathrm{G}>\mathrm{A}$ promoter polymorphism in RA susceptibility has been investigated in various populations yielding contradictory results. Some studies have reported a positive association of TNF- $\alpha-308$ alleles with $\mathrm{RA}^{3,16,31-34}$ while others have reported lack of association with RA. ${ }^{36,48-52}$ In conformity with the majority of previous studies, the present study failed to demonstrate any association between the TNF- $\alpha-308 \mathrm{G}>\mathrm{A}$ promoter polymorphism and $\mathrm{RA}$ in cohort 1 . Interestingly, the comparison between RA patients who were RF positive and $\mathrm{RF}$ negative revealed a marginally significant difference in the allele frequencies $(p=0.05$, $\mathrm{OR}=2.86,0.96-8.52$ at $95 \% \mathrm{CI}$ ). The frequency of the A allele was higher in RA positive patients ( $15 \%$ vs. $5.8 \%$, respectively). It appears that the presence of $\mathrm{A}$ allele in $\mathrm{RA}$ positive patients may increase susceptibility to RA in cohort 1 i.e. the population of Punjab. However, this finding needs to be confirmed with a larger sample size. Moreover, no association was shown between TNF- $\alpha-308$ G $>$ A promoter polymorphism with susceptibility to RA in overall patients and controls in cohort 2. However, the association of genotypic frequencies and marginal association of allele frequencies in males suggested a sexspecific association between TNF- $\alpha-308$ G $>A$ polymorphism with RA in Jammu and Kashmir population. If these sex-specific differences can be replicated, it might be considered an important susceptibility factor in male patients. ${ }^{53}$ Presence of AA genotype in only females reflects a trend towards the sex-specific effect of the genotype with RA. However, no statistical significance was detected for females in both cohorts. Thus analysis on larger sample sizes is required to ascertain any sex-specific association. The association between the TNF- $\alpha-308 \mathrm{G}>\mathrm{A}$ polymorphism and RA can be explained in many ways as it is located in the regulatory region of TNF- $\alpha$ gene where the secretion of TNF- $\alpha$ is regulated. Still, the role of polymorphism in both North Indian populations needs to be analyzed on a larger sample size.

In conclusion, TNF- $\alpha-308 \mathrm{G}>\mathrm{A}$ polymorphism does not appear to be associated with RA in the population of Punjab, while it is marginally associated with RA in males in Jammu and Kashmir.

\section{Acknowledgements}

The financial assistance to Priyanka Raina and Priyanka by the Punjab State Council for Science and Technology is duly acknowledged. The assistance of Dr. Bella Mahajan, Head, Department of Microbiology, Government Medical College, Jammu in sample collection is also humbly acknowledged.

\section{Declaration of conflicting interests}

The authors declared no conflicts of interest with respect to the authorship and/or publication of this article.

\section{Funding}

The financial assistance to Priyanka Raina and Priyanka by the Punjab State Council for Science and Technology is duly acknowledged.

\section{REFERENCES}

1. World Health Organization. Chronic rheumatic conditions. 2012.

2. Goldsby RA, Kindt TJ, Osborne BA. Kuby Immunology. 6th ed. New York: W.H. Freeman \& Company; 2006.

3. Chen R, Fang M, Cai Q, Duan S, Lv K, Cheng N, et al. Tumor necrosis factor alpha -308 polymorphism is associated with rheumatoid arthritis in Han population of Eastern China. Rheumatol Int 2007;28:121-6.

4. Firestein GS. Evolving concepts of rheumatoid arthritis. Nature 2003;423:356-61.

5. Grant SF, Thorleifsson G, Frigge ML, Thorsteinsson J, Gunnlaugsdóttir B, Geirsson AJ, et al. The inheritance of rheumatoid arthritis in Iceland. Arthritis Rheum 2001;44:2247-54.

6. Brennan FM, McInnes IB. Evidence that cytokines play a role in rheumatoid arthritis. $\mathrm{J}$ Clin Invest 2008;118:3537-45.

7. Janeway C. Immunobiology: The Immune System in Health and Disease. 6th ed. Garlan: Taylor \& Francis Group; 2005.

8. Shapiro JA, Koepsell TD, Voigt LF, Dugowson CE, Kestin M, Nelson JL. Diet and rheumatoid arthritis in women: a possible protective effect of fish consumption. Epidemiology 1996;7:256-63.

9. Kirkham BW, Lassere MN, Edmonds JP, Juhasz KM, Bird PA, Lee CS, et al. Synovial membrane cytokine 
expression is predictive of joint damage progression in rheumatoid arthritis: a two-year prospective study (the DAMAGE study cohort). Arthritis Rheum 2006;54:1122-31.

10. Nemec P, Pavkova-Goldbergova M, Stouracova M, Vasku A, Soucek M, Gatterova J. Polymorphism in the tumor necrosis factor-alpha gene promoter is associated with severity of rheumatoid arthritis in the Czech population. Clin Rheumatol 2008;27:59-65.

11. Plenge RM, Cotsapas C, Davies L, Price AL, de Bakker PI, Maller J, et al. Two independent alleles at 6 q23 associated with risk of rheumatoid arthritis. Nat Genet 2007;39:1477-82.

12. Saxne T, Palladino MA Jr, Heinegård D, Talal N, Wollheim FA. Detection of tumor necrosis factor alpha but not tumor necrosis factor beta in rheumatoid arthritis synovial fluid and serum. Arthritis Rheum 1988;31:1041-5.

13. Keffer J, Probert L, Cazlaris H, Georgopoulos $\mathrm{S}$, Kaslaris E, Kioussis $\mathrm{D}$, et al. Transgenic mice expressing human tumour necrosis factor: a predictive genetic model of arthritis. EMBO J 1991;10:4025-31.

14. Wilson AG, de Vries N, Pociot F, di Giovine FS, van der Putte LB, Duff GW. An allelic polymorphism within the human tumor necrosis factor alpha promoter region is strongly associated with HLA A1, B8, and DR3 alleles. J Exp Med 1993;177:557-60.

15. Hajeer $\mathrm{AH}$, Hutchinson IV. Influence of TNFalpha gene polymorphisms on TNFalpha production and disease. Hum Immunol 2001;62:1191-9.

16. Abraham LJ, Kroeger KM. Impact of the -308 TNF promoter polymorphism on the transcriptional regulation of the TNF gene: relevance to disease. $\mathrm{J}$ Leukoc Biol 1999;66:562-6.

17. Cuenca J, Pérez CA, Aguirre AJ, Schiattino I, Aguillón JC. Genetic polymorphism at position-308 in the promoter region of the tumor necrosis factor (TNF): implications of its allelic distribution on susceptibility or resistance to diseases in the Chilean population. Biol Res 2001;34:237-41.

18. Yen JH, Chen CJ, Tsai WC, Lin CH, Ou TT, Wu CC, et al. Tumor necrosis factor promoter polymorphisms in patients with rheumatoid arthritis in Taiwan. $J$ Rheumatol 2001;28:1788-92.

19. Cvetkovic JT, Wallberg-Jonsson S, Stegmayr B, Rantapaa-Dahlqvist S, Lefvert AK. Susceptibility for and clinical manifestations of rheumatoid arthritis are associated with polymorphisms of the TNFalpha, IL-1beta, and IL-1Ra genes. J Rheumatol 2002;29:212-9.

20. Seitz M, Wirthmüller U, Möller B, Villiger PM. The -308 tumour necrosis factor-alpha gene polymorphism predicts therapeutic response to TNFalpha-blockers in rheumatoid arthritis and spondyloarthritis patients. Rheumatology (Oxford) 2007;46:93-6.

21. Fonseca JE, Cavaleiro J, Teles J, Sousa E, Andreozzi VL, Antunes M, et al. Contribution for new genetic markers of rheumatoid arthritis activity and severity: sequencing of the tumor necrosis factor-alpha gene promoter. Arthritis Res Ther 2007;9:R37.

22. Arnett FC, Edworthy SM, Bloch DA, McShane DJ, Fries JF, Cooper NS, et al. The American Rheumatism Association 1987 revised criteria for the classification of rheumatoid arthritis. Arthritis Rheum 1988;31:315-24.

23. Miller SA, Dykes DD, Polesky HF. A simple salting out procedure for extracting DNA from human nucleated cells. Nucleic Acids Res 1988;16:1215.

24. Sambrook J, Russel DW. Molecular cloning-a laboratory manual. Cold spring harbor, NewYork, 2001.

25. Gupta V, Sehajpal PK. Rapid detection of single nucleotide (-308) polymorphism in TNF- $\alpha$ promoter using ARMS-PCR. Curr Sci India 2003;85:11.

26. Snehalatha C, Viswanathan V, Ramachandran A. Cutoff values for normal anthropometric variables in asian Indian adults.Diabetes Care 2003;26:1380-4.

27. Rego-Pérez I, Fernández-Moreno M, Blanco FJ. Gene polymorphisms and pharmacogenetics in rheumatoid arthritis. Curr Genomics 2008;9:381-93.

28. Al-Rayes H, Al-Swailem R, Albelawi M, Arfin M, Al-Asmari A, Tariq M. TNF- $\alpha$ and TNF- $\beta$ Gene Polymorphism in Saudi Rheumatoid Arthritis Patients. Clin Med Insights Arthritis Musculoskelet Disord 2011;4:55-63.

29. Bouma G, Crusius JB, Oudkerk Pool M, Kolkman JJ, von Blomberg BM, Kostense PJ, et al. Secretion of tumour necrosis factor alpha and lymphotoxin alpha in relation to polymorphisms in the TNF genes and HLADR alleles. Relevance for inflammatory bowel disease. Scand J Immunol 1996;43:456-63.

30. Louis E, Franchimont D, Piron A, Gevaert Y, SchaafLafontaine N, Roland S, et al. Tumour necrosis factor (TNF) gene polymorphism influences TNF-alpha production in lipopolysaccharide (LPS)-stimulated whole blood cell culture in healthy humans. Clin Exp Immunol 1998;113:401-6.

31. Oregón-Romero E, Vázquez-Del Mercado M, RuizQuezada SL, Navarro-Hernández RE, Rangel-Villalobos $\mathrm{H}$, Martínez-Bonilla $\mathrm{G}$, et al. Tumor necrosis factor alpha-308 and -238 polymorphisms in rheumatoid arthritis. Association with messenger RNA expression and sTNF-alpha. J Investig Med 2008;56:937-43.

32. Seki N, Kamizono S, Yamada A, Higuchi T, Matsumoto $\mathrm{H}$, Niiya $\mathrm{F}$, et al. Polymorphisms in the 5 -flanking region of tumor necrosis factor-alpha gene in patients with rheumatoid arthritis. Tissue Antigens 1999;54:194-7.

33. Gambhir D, Lawrence A, Aggarwal A, Misra R, Mandal SK, Naik S. Association of tumor necrosis factor alpha and IL-10 promoter polymorphisms with rheumatoid arthritis in North Indian population. Rheumatol Int 2010;30:1211-7.

34. Hussein YM, Mohamed RH, Pasha HF, El-Shahawy EE, Alzahrani SS. Association of tumor necrosis factor alpha and its receptor polymorphisms with rheumatoid arthritis in female patients. Cell Immunol 2011;271:192-6. 
35. Brinkman BM, Huizinga TW, Kurban SS, van der Velde EA, Schreuder GM, Hazes JM, et al. Tumour necrosis factor alpha gene polymorphisms in rheumatoid arthritis: association with susceptibility to, or severity of, disease? $\mathrm{Br} \mathrm{J}$ Rheumatol 1997;36:516-21.

36. Emonts M, Hazes MJ, Houwing-Duistermaat JJ, van der Gaast-de Jongh CE, de Vogel L, Han HK, et al. Polymorphisms in genes controlling inflammation and tissue repair in rheumatoid arthritis: a case control study. BMC Med Genet 2011;12:36.

37. Bhasin MK, Nag S. A demographic profile of the people of Jammu and Kashmir. J. Hum. Ecol 2002;13:1-55.

38. Lo SF, Huang CM, Wu MC, Wu JY, Tsai FJ. Lack of association of tumor necrosis factor alpha gene polymorphism in patients with rheumatoid arthritis in central Taiwan. Rheumatol Int 2003;23:151-3.

39. Mugnier B, Balandraud N, Darque A, Roudier C, Roudier J, Reviron D. Polymorphism at position -308 of the tumor necrosis factor alpha gene influences outcome of infliximab therapy in rheumatoid arthritis. Arthritis Rheum 2003;48:1849-52.

40. Khanna D, Wu H, Park G, Gersuk V, Gold RH, Nepom GT, et al. Association of tumor necrosis factor alpha polymorphism, but not the shared epitope, with increased radiographic progression in a seropositive rheumatoid arthritis inception cohort. Arthritis Rheum 2006;54:1105-16.

41. Masi AT, Aldag JC, Chatterton RT, Adams RF, Kitabchi AE. Adrenal androgen and glucocorticoid dissociation in premenopausal rheumatoid arthritis: a significant correlate or precursor to onset? Z Rheumatol 2000;59 Suppl 2:II/54-61.

42. Lawrence RC, Helmick CG, Arnett FC, Deyo RA, Felson DT, Giannini EH, et al. Estimates of the prevalence of arthritis and selected musculoskeletal disorders in the United States. Arthritis Rheum 1998;41:778-99.

43. Wilder RL. Neuroimmunoendocrinology of the rheumatic diseases: past, present, and future. Ann N Y Acad Sci 2002;966:13-9.

44. Arnold F, Parasuraman S, Arokiasamy P, Kothari M. Nutrition in India, National family health survey-3
2009. Retrieved on 7/12/2013. http://www.nfhsindia. org/nfhs3.pdf.

45. Khokhar KK, Kaur G, Sidhu S. Prevalence of Obesity in Working Premenopausal and Postmenopausal Women of Jalandhar District, Punjab. J Hum Ecol 2010;29:57-62.

46. de Godoy I, Donahoe M, Calhoun WJ, Mancino J, Rogers RM. Elevated TNF-alpha production by peripheral blood monocytes of weight-losing COPD patients. Am J Respir Crit Care Med 1996;153:633-7.

47. Delano MJ, Moldawer LL. The origins of cachexia in acute and chronic inflammatory diseases. Nutr Clin Pract 2006;21:68-81.

48. Wilson AG, de Vries N, van de Putte LB, Duff GW. A tumour necrosis factor alpha polymorphism is not associated with rheumatoid arthritis. Ann Rheum Dis 1995;54:601-3.

49. Vinasco J, Beraún Y, Nieto A, Fraile A, Mataran L, Pareja E, et al. Polymorphism at the TNF loci in rheumatoid arthritis. Tissue Antigens 1997;49:74-8.

50. Ateş A, Kinikli G, Düzgün N, Duman M. Lack of association of tumor necrosis factor-alpha gene polymorphisms with disease susceptibility and severity in Behçet's disease. Rheumatol Int 2006;26:348-53.

51. Lee YH, Rho YH, Choi SJ, Ji JD, Song GG. Association of TNF-alpha -308 G/A polymorphism with responsiveness to TNF-alpha-blockers in rheumatoid arthritis: a meta-analysis. Rheumatol Int 2006;27:157-61.

52. Pavy S, Toonen EJ, Miceli-Richard C, Barrera P, van Riel PL, Criswell LA, et al. Tumour necrosis factor alpha -308G->A polymorphism is not associated with response to TNFalpha blockers in Caucasian patients with rheumatoid arthritis: systematic review and metaanalysis. Ann Rheum Dis 2010;69:1022-8.

53. Hüffmeier U, Reis A, Steffens M, Lascorz J, Böhm B, Lohmann $\mathrm{J}$, et al. Male restricted genetic association of variant R620W in PTPN22 with psoriatic arthritis. $\mathrm{J}$ Invest Dermatol 2006;126:932-5.

54. Ardebili SM, Yeghaneh T, Gharesouran J, Rezazadeh M, Farhoudi M, Ayromlou H, et al. Genetic association of TNF- $\alpha-308 \mathrm{G} / \mathrm{A}$ and $-863 \mathrm{C} / \mathrm{A}$ polymorphisms with late onset Alzheimer's disease in Azeri Turk population of Iran. J Res Med Sci 2011;16:1006-13. 